\title{
Emergency response and permanent measures for large landslide dams triggered by the 2004 Mid-Niigata Prefecture Earthquake in Japan
}

\author{
Yoshiki NAGAI $^{1}$, Jun MARUYAMA ${ }^{1}$, Katsumi YOSHIDA ${ }^{1}$, and Takao YAMAKOSHI ${ }^{2}$ \\ 1 Yuzawa Sabo Office, Hokuriku Regional Development Bureau, Ministry of Land, Infrastructure and Transport, \\ Kandachi 23, Yuzawa Town, Minami-Uonuma gun, Niigata, 949-6102 Japan (yuzawa1 @ hrr.mlit.go.jp) \\ 2 Public Works Research Institute, 1-6 Minamihara, Tsukuba, Ibaraki 305-8516, Japan
}

\begin{abstract}
We describe various management operations undertaken by the Japanese central government in response to sediment-related disasters caused by the Mid-Niigata Prefecture Earthquake of October 23, 2004. The operations included the implementation of emergency and permanent measures for stabilizing the landslide dam in Higashi-Takezawa district as well as policy development of a sabo (erosion and sediment control) master plan for the Imogawa River basin.

The earthquake caused many landslides in the Imogawa River basin. The landslide that occurred in Higashi-Takezawa district formed a large dam that reached a height of $30 \mathrm{~m}$, which imposed a risk of the water level rising high enough to overflow and cause the blockage to collapse. Therefore, sabo works were undertaken by the central government to plan and implement emergency countermeasures. The Yuzawa Sabo Office of the Ministry of Land, Infrastructure, and Transport was directly responsible for these emergency measures, which included pumping out water from the reservoir to reduce the water level and prevent the landslide dam collapsing, and constructing a temporary drainage channel in preparation for the coming snowmelt and rainy season. These emergency measures ensured the safety of the downstream area. The local headquarters established in the Yuzawa Sabo Office monitored the changing conditions in the area, and planned and implemented further preventive and recovery measures while consulting with experts. In addition, an advisory committee on the landslide dams in the Imogawa River basin was established, and ad hoc meetings were held to discuss emergency and permanent measures for stabilizing the dams and developing a sabo master plan for the Imogawa River basin. Helicopter and terrestrial monitoring took place during the snowmelt and rainy season after the earthquake. In addition, aerial photo surveys and aerial laser scanning surveys were conducted to follow up with the sediment yield and runoff processes. This monitoring contributes to the security of residents and construction workers, and to the revision of the sabo master plan.
\end{abstract}

Keywords: earthquake, collapse, landslide, landslide dam, emergency action, permanent measure, sabo master plan, Imogawa

\section{INTRODUCTION}

At 17:56 on October 23, 2004, an earthquake of magnitude 6.8 struck Niigata Prefecture in northeastern Japan. In the town of Kawaguchi close to the hypocenter, seismic activity with an intensity of a 7 on the Japan Meteorological Agency (JMA) scale (J.M.A., 1996) was recorded for the first time since the beginning of seismometer recordings. Strong aftershocks followed one after another, including four that registered a seismic intensity of 6 (Table 1), defined on the JMA scale as an intensity at which people cannot remain standing.

The earthquake caused many landslides throughout Niigata Prefecture. In particular, in the
Imogawa River basin close to the hypocenter, a large volume of sediment produced by the landslides accumulated in river courses, causing severe blockage. As a result, the entire basin area suffered tremendous damage, including disruption of roads and flooding of houses due to dammed-up water courses. A total of 1,419 minor landslides and 75 major landslides occurred in the Imogawa River basin as a result of this earthquake.

Responding to the enormous impact of so many landslides, the Yuzawa Sabo Office of the Hokuriku Regional Development Bureau, Ministry of Land, Infrastructure, and Transport (MLIT) immediately prepared for emergency operations. Helicopter surveys and terrestrial patrols were conducted to 
Table 1 Seismic intensity recorded during the Mid Niigata Prefecture Earthquake (Press release by JMA, as of 2004.12.28)

\begin{tabular}{c|c|c} 
Date & Time & $\begin{array}{l}\text { Maximum } \\
\text { Seismic Intensity }\end{array}$ \\
\hline & $17: 56$ & 7 \\
& $17: 59$ & 5 upper \\
& $18: 03$ & 5 upper \\
& $18: 07$ & 5 upper \\
& $18: 11$ & 6 upper \\
Oct.23 & $18: 34$ & 6 upper \\
& $18: 36$ & 5 lower \\
& $18: 57$ & 5 upper \\
& $19: 36$ & 5 lower \\
& $19: 45$ & 6 lower \\
& $19: 48$ & 5 lower \\
\hline Oct.24 & $14: 21$ & 5 upper \\
\hline & $0: 28$ & 5 lower \\
Oct.25 & $6: 04$ & 5 upper \\
& $10: 40$ & 6 lower \\
& $8: 57$ & 5 upper \\
& $11: 15$ & 5 upper \\
& $3: 43$ & 5 lower \\
& $18: 30$ & 5 lower \\
\hline
\end{tabular}

provide firsthand information to the Niigata to stabilize the landslide dams as well as the basic policies in a sabo master plan for the entire Imogawa River basin developed by members of the Advisory Committee on Landslide Dams in the Imogawa River basin.

\section{OVERVIEW OF THE IMOGAWA RIVER BASIN}

The Imogawa River basin is located in Niigata Prefecture. Its drainage area is $38.4 \mathrm{~km}^{2}$, the channel length is $17.2 \mathrm{~km}$, and the average bed slope is $1 / 70$. It is a right tributary of the Uonogawa River in the Shinanogawa River drainage system. It originates around Mt. Sarukuradake (679 $\mathrm{m}$ a.s.l.) and flows south where it joins the Uonogawa River (Fig. 1).

Pliocene (Tertiary Period) to Pleistocene (Quaternary Period) formations are distributed throughout the Imogawa River basin. They are mainly composed of sedimentary rocks such as mudstone, alternating sandstone and mudstone, and

October 24, the day after the earthquake, a helicopter patrol confirmed that numerous large-scale landslide dams had formed in the Imogawa River basin, including a particularly major one in Higashi-Takezawa district with a blockage height of up to $30 \mathrm{~m}$. The water level in the upstream area rose dramatically and the threat of overflow and subsequent collapse of the landslide dam was imminent. Therefore, the central government decided to undertake immediate emergency action, and the Yuzawa Sabo Office was assigned the frontline responsibility.

Landslide-dam phenomena have been recorded worldwide (Korup, 2002), but few reports have described emergency actions during a landslide-dam crisis in English. A situation in Ecuador was one of the rare cases when all human efforts to mitigate the damage of the inevitable outburst of a huge landslide dam with a capacity of 130 million $\mathrm{m}^{3}$ was well documented (Plaza-Nieto and Zevallos, 1994).

In this report, we describe the emergency actions that were undertaken for the landslide dam that formed in Higashi-Takezawa district due to a landslide triggered by the Mid-Niigata Prefecture Earthquake. We also describe the plan for instating permanent measures

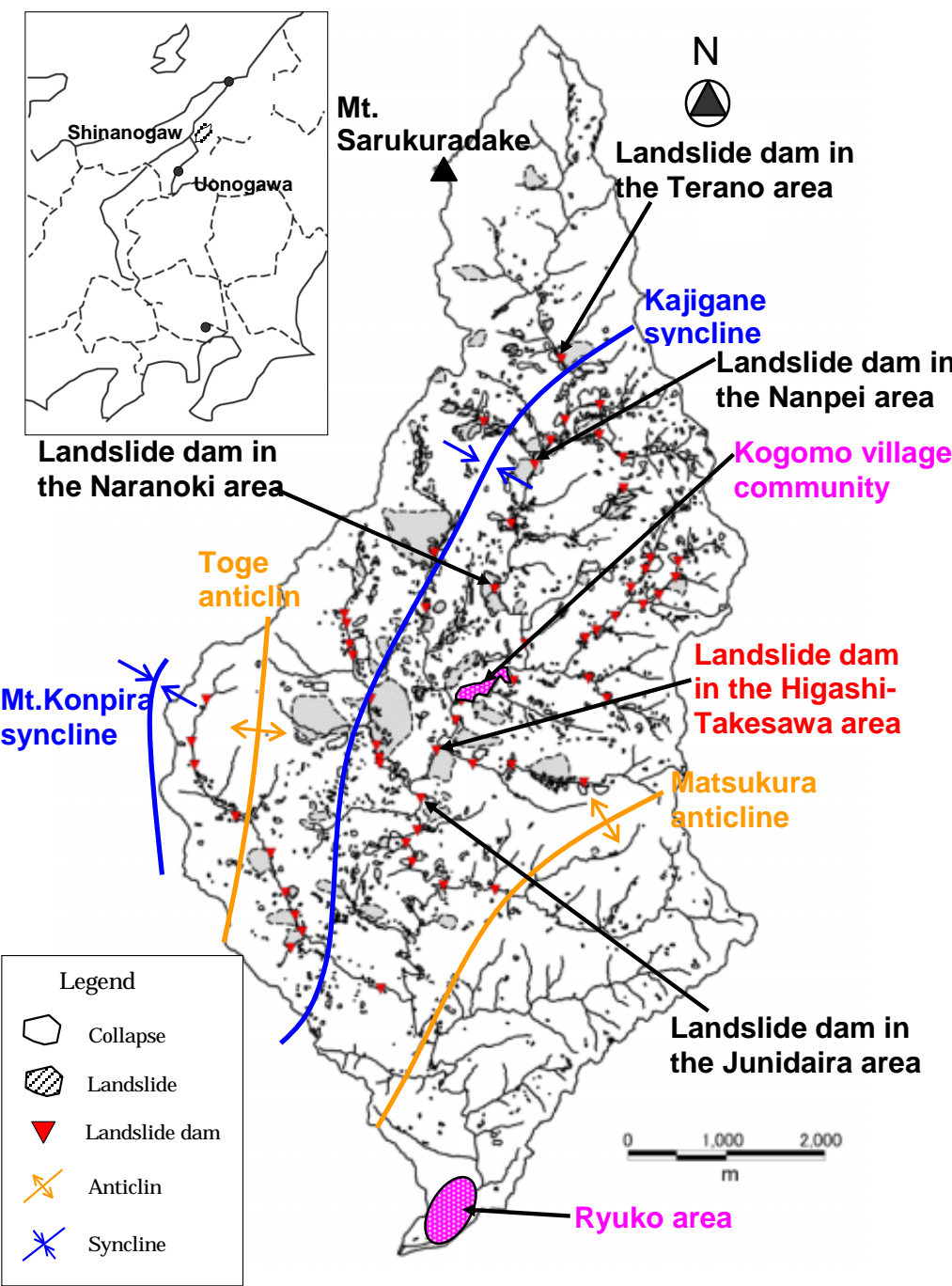

Fig. 1 Collapses, landslides, and landslide dams in the Imogawa River Basin caused by the Mid Niigata Prefecture 


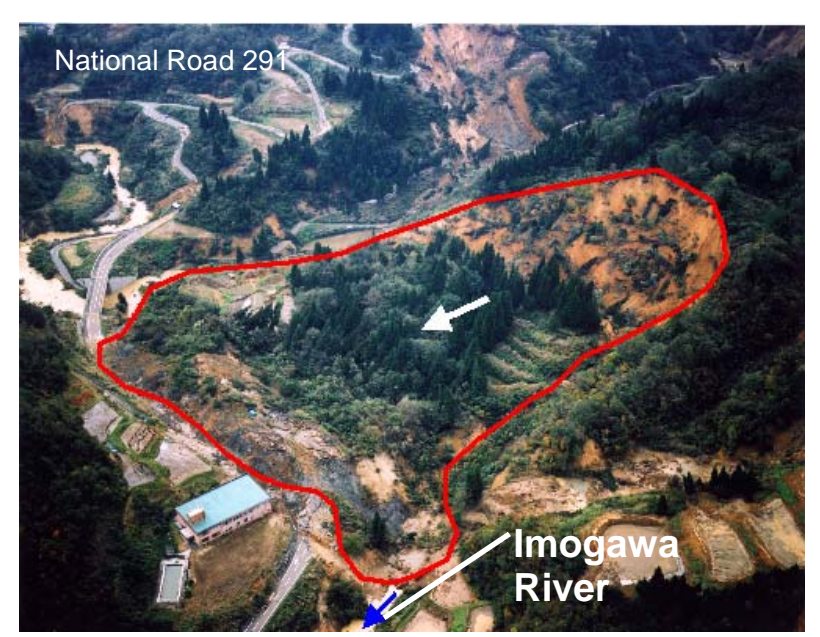

Photo 1 Landslide dam in the Higashi-Takesawa dist.

(Photographed on Nov. 3, 2004)

sandstone. The formations are distributed in a north-northeast to south-southwest direction, and are associated with several fold axes: the Mt. Konpira syncline, the Toge anticline, the Kajigane syncline, and the Matsukura anticline, in order from west to east. The interval between fold axes is about $1 \mathrm{~km}$ (Kobayashi et al. 1990 \& Yanagisawa et al. 1986).

Cracks tend to occur in the formations around the fold axes due to tectonic movement. The geology along the Imogawa River basin consists of relatively new and fragile sedimentary rocks of the Neogene Period or later. These rocks are weak because of weathering, and easily become claylike under the influence of groundwater and other factors. This, combined with the cracks in the formations, make the area one of the major landslide-prone areas in Japan.

Most of the landslides triggered by the earthquake occurred in areas located between the Kajigane syncline, which runs north to south in the center of the basin, and the Toge and Matsukura anticlines, which lie to the east and west of the Kajigane syncline.

An enormous amount of sediment produced by the landslides accumulated in the riverbed and formed landslide dams at 55 places in the Imogawa River basin. Five of these with particularly large volumes of sediment formed along the main stream of the Imogawa River basin in the areas of Terano, Nanpei, Naranoki, Higashi-Takezawa, and Junidaira.

\section{EMERGENCY RESPONSE TO THE FORMATION OF THE LANDSLIDE DAM IN HIGASHI-TAKEZAWA DISTRICT}

At the landslide dam in Higashi-Takezawa district, the water level started rising soon after the river course became blocked with sediment; the details of this are in Section 3.3.1. The Kogomo village (the former village of Yamakoshi) community suffered severe inundation damage. Because of the major rise in water level in the upstream area, a risk existed of an overflow as well as the collapse of the landslide dam. An overflow would put the downstream Ryuko district in danger of major damage by flood or debris flow.

The Niigata Prefecture government immediately implemented emergency action, but the appropriate data for coping with such a large-scale landslide dam were not available. Therefore, at the request of the prefecture governor, emergency action was undertaken by the central government starting on November 5. The Yuzawa Sabo Office was assigned to supervise this work. At that time, the water level in the upstream area had risen to within $6 \mathrm{~m}$ of the overflow danger level (161 $\mathrm{m}$ a.s.1.). As a result of the preliminary on-site survey and the aerial laser scanning survey, the dimensions of the landslide dam were quantitatively measured and the possible peak flow discharge was evaluated to be $1,260 \mathrm{~m}^{3} / \mathrm{s}$ (N.I.L.I.M. et., 2005) according to the existing peak-flow discharge prediction equation (Costa, 1988)

$$
Q_{\max }=6.3 H^{1.59}
$$

where $Q_{\max }$ is the peak flow discharge and $H$ is the height of the landslide dam.

\subsection{Challenges and objectives of emergency action}

Numerous challenges had to be met in implementing emergency action for the landslide dam in Higashi-Takezawa district, and these are described below. Emergency measures had to be completed before the snowmelt season as this area is well-known for its heavy snowfall, and a snow cover of $3 \mathrm{~m}$ is not unusual.

[Challenges]

[1] Roads to the working site were severely disrupted by the earthquake, making it difficult to transport construction equipment and material for emergency measures.

[2] The water level on the upstream side of the landslide dam was rising daily and had to be reduced as soon as possible.

[3] Securing safe water discharge from the landslide dam in the snowmelt season was needed.

To overcome these difficulties, emergency measures objectives were established as follows: [Concrete objectives]

[1] To transport equipment and materials for 
emergency action by helicopter, and to open up the blocked roads for carrying heavy machinery by land.

[2] To lower the water level by constructing an emergency pumping drainage system.

[3] To avoid overflow of water from the landslide dam at the time of the snowmelt by constructing a temporary spillway with a sufficient cross-sectional profile.

\subsection{Implementation structure for emergency action}

To implement emergency measures appropriate to the continuously changing situation at the site, the Local Headquarters for Emergency Actions for Landslide Dams at the Imogawa River basin, headed by the Director of the Land Conservation Division of the MLIT Sabo Department, was established at the Yuzawa Sabo Office. The local headquarters was operated until December 28 when emergency construction activities were completed on the temporary diversion channel in Higashi-Takezawa district for discharging snowmelt water. During that period, countermeasures were planned and implemented with the participation of over 400 people, including staff from the Sabo Department of the MLIT River Bureau, the River Department of the MLIT Hokuriku Regional Development Bureau and its local offices, Niigata University, and the National Institute for Land and Infrastructure Development.

\subsection{Emergency action for the landslide dam in Higashi-Takezawa district}

\subsubsection{Conditions of the landslide dam}

The landslide dam in Higashi-Takezawa district was formed as a result of a landslide that occurred on the left bank slope of the Imogawa River. The size of the slide was estimated to be $350 \mathrm{~m}$ long, $295 \mathrm{~m}$ wide, and $30 \mathrm{~m}$ deep, and the extent of the original landslide displacement at the upper part of the slope was about $70 \mathrm{~m}$. The end of the landslide mass blocked the Imogawa River and reached National Road 291 running parallel to the river on the opposite bank. The volume of sediment blocking the river course was $655,940 \mathrm{~m}^{3}$ and the maximum volume of dammed-up water was $2,560,500 \mathrm{~m}^{3}$ at its highest level.

Based on the results of a site reconnaissance, the sliding soil mass itself was judged to be stable, and only a slight possibility of collapsing from water pressure was determined to exist because the longitudinal length of the blockage was sufficiently large compared to the water depth. However, as the water level continued to rise day after day, drainage of the dammed-up water was urgently required to prevent the blockage from collapsing due to the overflow.

\subsubsection{Emergency action for the landslide dam}

In Higashi-Takezawa district, emergency action was taken while continuously monitoring the landslide on the left bank.

Helicopters were used to transport the necessary construction materials to the worksite, and an access road was constructed to bring in heavy machinery by land. A crossing road and a floating walkway were also installed over the area where the water had dammed up.

[1] Construction of emergency pumping drainage system

To prevent overflow, an emergency pumping drainage system was installed at the landslide dam with a pipe system length of $102 \mathrm{~m}$. Twelve pumps with a maximum drainage capacity of 0.5 $\mathrm{m}^{3} / \mathrm{s}$ were installed on the upstream side and were operated $24 \mathrm{~h}$ a day. In addition, large sandbags (1 t/bag) were piled on the lower part of the landslide soil mass to form an earth embankment. However, the water level continued to rise and the ground around the outlet of the pumping drainage system was quickly eroded. To avoid the collapse of the landslide dam due to the progress of this erosion, it was decided to change the pumping drainage path, which initially been constructed on shortest but most erodible route. The path was changed to terminate in an erosion-resistant area outside the landslide soil mass, through the area of the former Higashi-Takezawa Elementary School (Fig. 2, Photo 2).

[2] Installation of a temporary drainage conduit

To reduce the water level at the upstream side before starting excavation of the temporary drainage channel, a temporary drainage conduit

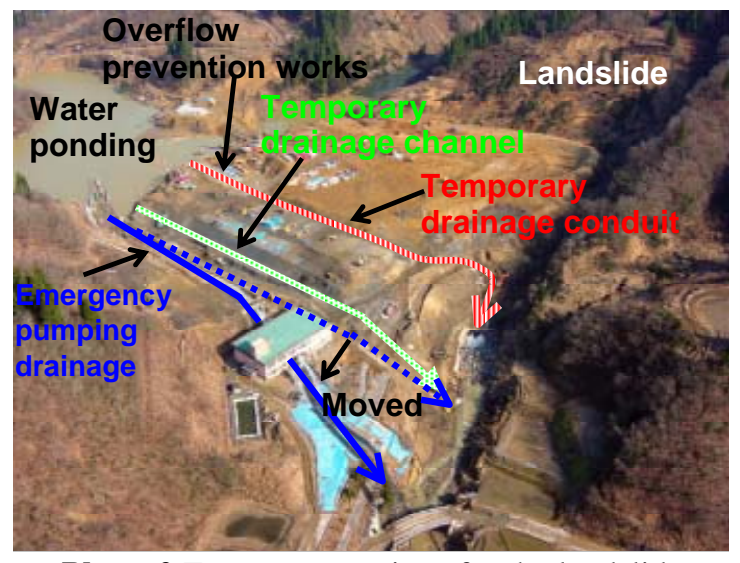

Photo 2 Emergency actions for the landslide dam in the Higashi-Takesawa dist. (Photographed on Dec. 14, 2004) 


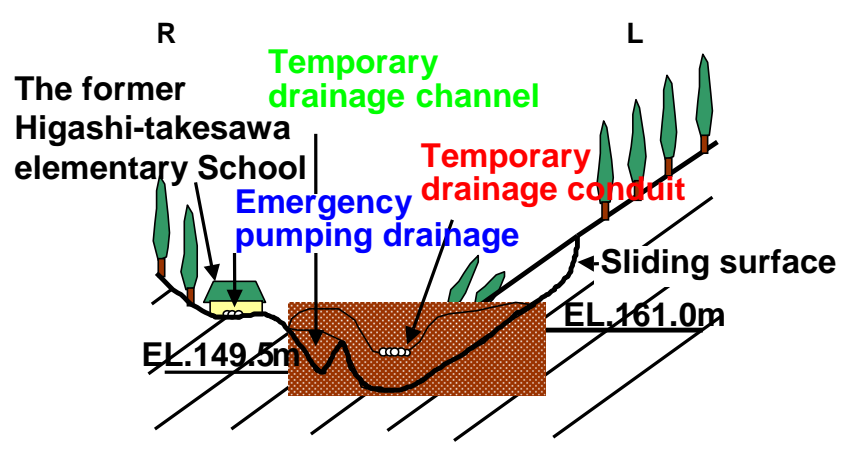

Fig. 2 Cross-section of the landslide dam in the Higashi-Takesawa dist.

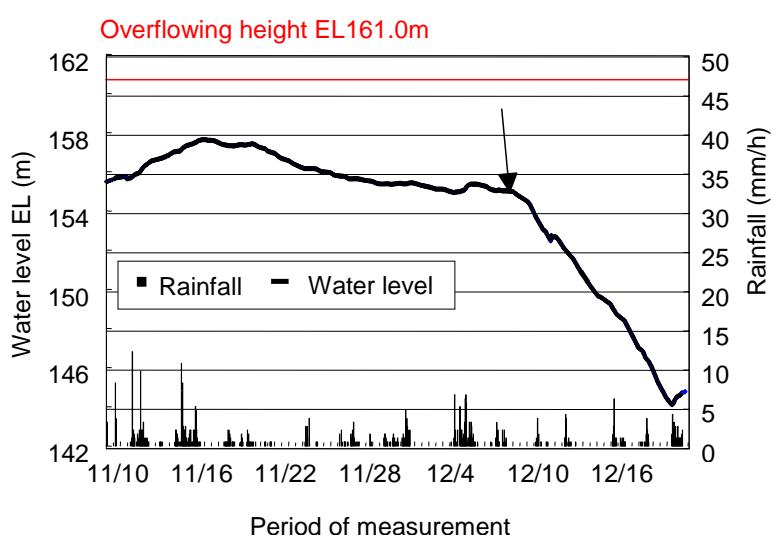

Fig. 3 Water level change at the landslide dam in the Higashi-Takesawa area. Both the water level and rainfall were measured at this location. Before the earthquake, the riverbed at this location was about $130 \mathrm{~m}$ a.s.l. An arrow shows the moment that the water level abruptly reduced due to a combination of emergency drainage channel and temporary drainage conduit.

was installed by placing an inlet at a point $155 \mathrm{~m}$ a.s.l. The conduit was made of five high-density polyethylene pipes each with a diameter of $1.0 \mathrm{~m}$ and a length of $250 \mathrm{~m}$. This permitted the water above the inlet level at $155 \mathrm{~m}$ a.s.l. to flow downward at a rate of up to the full-pipe flow capacity of $10 \mathrm{~m}^{3} / \mathrm{s}$ even without pumps. This resulted in a considerable reduction of the water level (Fig. 3).

\section{[3] Construction of temporary spillway}

To discharge snowmelt water safely, a temporary 280-m-long spillway was constructed with a maximum gradient of $22.4 \%$. Considering the stability of the landslide during and after the construction, as well as the feasibility of completing construction before the start of the snowmelt season, the starting point of the temporary drainage channel was to be placed at $149.5 \mathrm{~m}$ a.s.l.

Since concrete-mixing trucks could not reach the work site due to road disruptions, the temporary spillway was constructed by shotcrete spraying (thickness $=20 \mathrm{~cm}$ ) on the graded river course section. To prevent scouring of the front foot of the landslide dam, protective blocks were transported to the site by helicopter and placed at the outlet of the channel. The spillway was large enough to handle the 1:100 year flow of 240 $\mathrm{m}^{3} / \mathrm{s}$ without decreasing the stability of the landslide dam.

Before starting construction of the temporary spillway, sediment was removed at the head of the landslide to prevent any reduction in stability upon excavation of a considerable amount of soil from the low area of the landslide soil mass.

\section{PERMANENT MEASURES FOR LANDSLIDE DAMS AND SABO MASTER PLANFOR THE ENTIRE IMOGAWA RIVER BASIN}

While taking emergency action for the large-scale landslide dam in Higashi-Takezawa district and other areas, it was also necessary to implement permanent measures for other landslide dams in the Imogawa River basin. A threat existed that discharge of a large amount of unstable sediment over a long period might affect not only the Imogawa River basin but also the Uonogawa River. Therefore, a sabo master plan that could adequately address these problems was urgently required.

Because the landslide dam measures and the sabo master plan had to deal with serious, rapid, and unprecedented devastation, advanced technologies that could meet severe topographical, meteorological, and construction conditions were required. Therefore, the Advisory Committee on Landslide Dams at the Imogawa River basin was established, chaired by Professor Hideaki Marui of Niigata University. Meetings to gather advice and suggestions from academics and experts were held four times between November 17, 2004 and March 1, 2005. The committee considered the scope of permanent measures for the landslide dam in Higashi-Takezawa and other districts, as well as the basic policies related to the sabo master plan for the entire Imogawa River basin.

\subsection{Permanent measures for landslide dams}

\subsubsection{Requirements for permanent measures}

It was decided that permanent measures in the areas of the landslide dams such as those in Higashi-Takezawa district were required to stabilize both the unstable soil mass that blocked the river courses and the landslide on the left bank.

To verify the safety of those measures, two stability analyses were conducted. One was to evaluate the stability of the landslide soil mass blocking the river. The other was to evaluate the 
stability of the residual soil mass of the landslide on the left-bank slope in the direction perpendicular to the river course. In addition, a numerical analysis was conducted to investigate the possibility of installing piping at the landslide dam to check the possibility of seepage erosion of the blockage and its safety.

In implementing permanent measures for landslide dams such as in Higashi-Takezawa district, the following two requirements had to be satisfied:

[1] Safe discharge of water produced by the expected design-rainfall specified in the sabo master plan to prevent erosion of the landslide dam due to overflow.

[2] Preventing the collapse of the landslide dam that could result from the pressure of the dammed-up water in the upstream area, and preventing the flooding of the downstream area with water and sediment.

\subsubsection{Permanent measures for the landslide dam in Higashi-Takezawa district}

Two measures were considered because the flood damage had reached the Kogomo community in the upstream area. One was to remove the blockage to the depth of the original riverbed; the other was to consolidate the blockage and maintain the present inlet height of $149.5 \mathrm{~m}$ a.s.l. in the temporary drainage channel. The original riverbed was $19.5 \mathrm{~m}$ lower than the height of the temporary spillway. To consolidate the blockage at the present height would cost approximately 1.4 billion yen and take 16 months to complete. Complete removal of the blockage would cost about 6.6 billion yen and require 37 months to complete, with the added requirement to dispose of $565,000 \mathrm{~m}^{3}$ of soil. Even though the landslide dam would be completely removed and flooding in the Kogomo community would be eliminated, it would have required many years to ensure the safety of the downstream area. Therefore, to promote the early return of evacuated villagers, a plan to consolidate the blockage at the present height and encourage evacuated villagers to settle in the other safe areas was recommended.

[1] Prevention of erosion due to overflow

Policy: To construct a channel to discharge water safely so that the landslide dam would not collapse by erosion due to overflowing.

Measures: Channel works (width $=2-14 \mathrm{~m}$, length $=230 \mathrm{~m}$, design discharge rate $=240 \mathrm{~m}^{3} / \mathrm{s}$ )

[2] Prevention of collapse due to water pressure

Policy: To install sabo dams downstream of the blockage to prevent its movement due to water pressure and to retain it within the sedimentation area of these dams.

Measures: Construction of two sabo dams 14.5 and $11.5 \mathrm{~m}$ high.

\subsection{Sabo master plan for the entire Imogawa River basin}

The advisory committee studied the possible future sediment movement based on the present condition of the Imogawa River basin, and recommended a sediment control policy for ensuring the safety of local areas in the face of sediment-related disasters caused by those phenomena.

\subsubsection{Possible sediment movement phenomena and sediment-related disasters}

The advisory committee issued the following predictions concerning possible sediment movement phenomena and sediment-related disasters in the Imogawa River basin:

[1] Because several landslide dams exist in the river courses, flooding of water and sediment may occur as a result of sediment discharge due to erosion or collapse of those landslide dams.

[2] Because a large amount of unstable sediment in the river basin may constantly flow out due to rainfall or snowmelt, aggradation of the riverbed may occur, resulting in flooding not only in the Imogawa River basin but also in the lower reaches of the Uonogawa River.

[3] It is highly likely that sediment-related disasters would be caused by the secondary erosion or secondary discharge of potential unstable sediment from the slope of shallow landslides and the foot of deep-seated landslides.

[4] It is highly likely that debris flows would be triggered in tributaries with steep riverbeds.

\subsubsection{Sediment control policy}

To ensure the safety of local areas in the case of future sediment-related disasters that may occur in the Imogawa River basin, the following sediment control policy was proposed:

[1] Remove or stabilize landslide dams.

[2] Control the discharge of unstable sediment accumulated in the riverbed.

[3] Initiate active measures to control the sediment yield from the slope of shallow landslides and from the foot of deep-seated landslides.

[4] Prevent the occurrence of debris flows and trap the discharged sediment by passive measures in the case of tributaries with steep riverbeds.

Based on this sabo master plan, the Yuzawa Sabo Office implemented the necessary sabo works in 


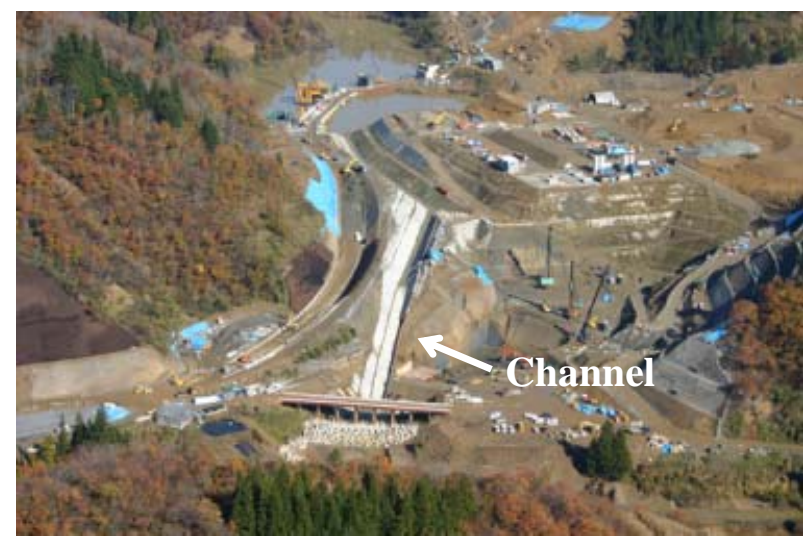

Photo 3 Landslide dam in Higashi-Takesawa area Photographed on 2005.11.21

order of priority at earthquake-damaged locations. The locations included large-scale landslide dams like the one in Higashi-Takezawa district where emergency countermeasures were undertaken. The Sabo Office coordinated its efforts with local reconstruction plans and completed all sabo works by March 2007 (Photo 3).

\section{MONITORING SYSTEM AND RESULTS OF A SURVEY IN THE IMOGAWA RIVER BASIN}

In the Imogawa River basin, vast quantities of unstable soil form natural dams that block rivers. When the ground is exposed to severe seismic motion, it may crack, slip, and loosen. Heavy rainfall may then carry the unstable sediment into rivers and generate new sediment on mountain slopes. Therefore, various monitoring activities have been carried out after the earthquake for two reasons:

1) To ensure the safety of sediment control project workers and people living in the downstream basin area.

2) To supplement the sabo master plan based on the ongoing situation of sediment yield and runoff currently occurring.

The monitoring activities have been performed in the Imogawa River basin at the sites shown in Fig. 4.

\subsection{Monitoring of the important countermeasure works and landslides}

To monitor Terano and Higashi-Takezawa districts in which the Imogawa River blockages were the most severe, fiber-optic communication cables and closed-circuit television (CCTV) cameras were immediately installed. Monitoring started immediately after the earthquake and has continued as of July 2007. In addition, more CCTV monitoring systems will be installed in the Imogawa
River basin to contribute to emergency warning and evacuation orders issued by the Niigata Prefecture government for sediment-related disasters that are considered to be likely in the areas affected by the Mid-Niigata Prefecture Earthquake.

Since this region receives heavy winter snowfall, access to the sites over snowy roads is difficult. A threat still exists of rockfalls and slope failures in the summer during periods of heavy rains, so the CCTV monitoring system will quickly and easily help clarify conditions in the drainage basin even in the event of an emergency. The Yuzawa Sabo Office will provide the CCTV images to the Niigata Prefecture government and the affected municipalities to enable them to respond to sediment-related disasters.

As previously noted, emergency measures were implemented immediately after the river was blocked by natural dams consisting of sliding soil mass or collapsed soil. It was essential to ensure the safety of workers because these measures were executed directly under or close to the sliding soil mass or collapsed slopes. In addition to taking direct safety measures to prevent the further collapse of slopes, precursor phenomena such as expansion of cracks or head scarps, the rise of water levels inside the landslide blocks, and the displacement (e.g, strain, inclination) of the collapsed slope had to be monitored to confirm landslide activity. Slope displacement is monitored by directly measuring the movement of the slope surface and using multipoint displacement gauges that evaluate the degree of risk based on the speed of movement.

Table 2 Monitoring activities in the Imogawa River

\begin{tabular}{|c|c|c|c|}
\hline CCTV & $\begin{array}{c}\text { Bore-hole water } \\
\text { level gauge }\end{array}$ & $\begin{array}{c}\text { Pipe-type strain } \\
\text { gauge }\end{array}$ & $\begin{array}{c}\text { Insertion type } \\
\text { bore-hole } \\
\text { inclinometer }\end{array}$ \\
\hline 5 & 173 & 72 & 18 \\
\hline $\begin{array}{c}\text { Buried type } \\
\text { inclinometer }\end{array}$ & $\begin{array}{c}\text { Ground surface } \\
\text { inclinometer }\end{array}$ & $\begin{array}{c}\text { Multi-point } \\
\text { displacement } \\
\text { gauge }\end{array}$ & $\begin{array}{c}\text { Water level } \\
\text { gauge }\end{array}$ \\
\hline 2 & 19 & 2 & 2 \\
\hline
\end{tabular}

5.2 Monitoring of the ponds formed by natural dams blocking rivers

In the Imogawa River basin, landslides triggered by the earthquake blocked the river and created ponds at many locations. As the water level in each pond rose, upstream areas were sometimes inundated, and further damage occurred when it overflowed the blockage and destroyed the landslide dam. Such problems threaten the safety of upstream and downstream residents and workers engaged in implementing emergency measures. For this reason, 


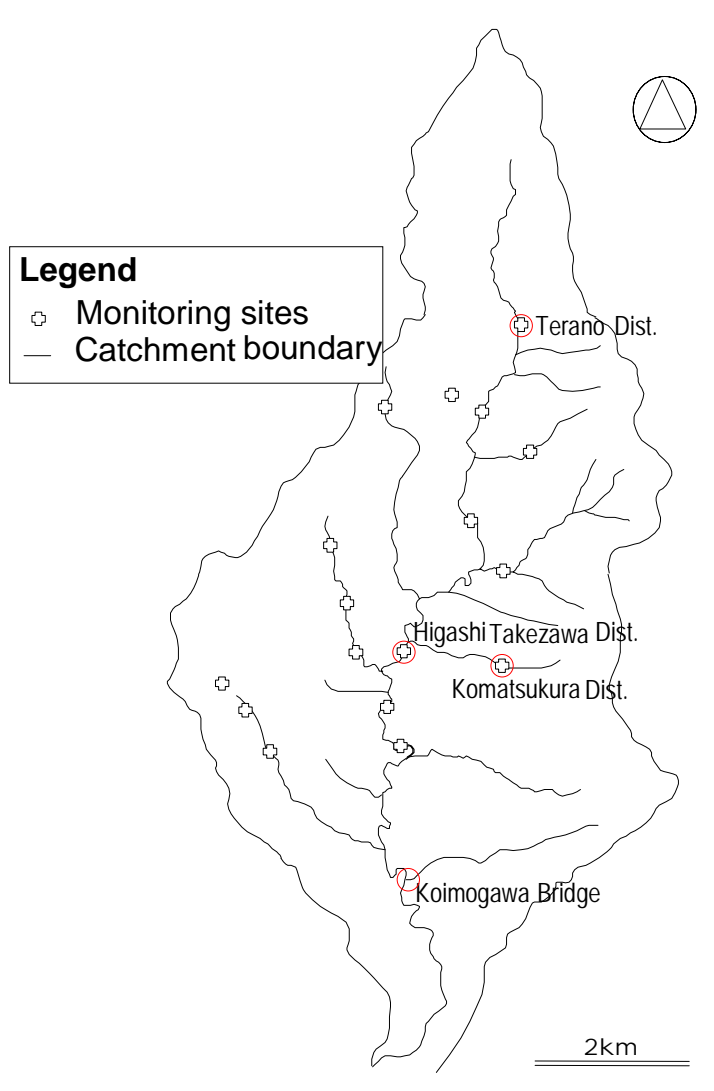

Fig. 4 Monitoring sites in the Imogawa River basin

the Yuzawa Sabo Office monitors the water level of the ponds. In addition to aerial observations from helicopter, monitoring is conducted by CCTV cameras, field surveys, water level gauges, and other devices.

\subsection{Monitoring and predicting of the snowmelt quantity}

In the Imogawa River basin following the disaster, sediment-related disasters were feared to occur as melting snow could cause new large-scale landslides that might block river courses and trigger the generation and runoff of debris flows. When a large snowmelt and heavy rainfall occur simultaneously at the end of the snowmelt season, the snowmelt quantity and melted snow runoff may rise, causing severe damage. Therefore, it is important to predict the snowmelt quantity when planning measures to prevent or mitigate sediment-related disasters.

The Yuzawa Sabo Office measures the actual snowmelt quantity and the river water level in the field, and performs calculations to predict the snowmelt quantity using the heat balance method. It provides all its employees with the following daily data on snow melting along the Imogawa River: average quantity of snow melting in the drainage basin, average rainfall in the drainage basin, and quantity of snow melting at the Komatsukura
Observation Point. The Sabo Office also provides information to the Niigata Prefecture Sabo Department and works to protect downstream residents and workers on sediment control structures from sediment-related disasters such as slope failures and debris flows. The next section provides an outline of field observations and prediction calculations of the melted snow amount performed to provide snowmelt forecasts.

\subsubsection{Field observations}

To measure the actual quantity of snowmelt each day, a lysimeter was installed in Komatsukura district. An ultrasonic water level gauge has been installed on the Koimogawa Bridge over the downstream Imogawa River to measure the water level, and also to monitor fluctuations in the flow rate caused by the runoff of snowmelt from the basin. The Yuzawa Sabo Office uses the monitoring data of the snowmelt and the flow rate as inputs for determining the following day's alert status. In Terano, Higashi-Takezawa, and Komatsumura districts, which were selected as representative of the Imogawa River basin, the quantity of solar insolation, air temperature, and rainfall that have a major impact on the snowmelt amount are measured and the results are used to estimate the amount of snowmelt.

\subsubsection{Snowmelt prediction}

Installing monitoring facilities across the entire Imogawa River basin would be difficult, yet it is necessary to predict the total snowmelt quantity and the peak flow discharge in the Imogawa River. For these reasons, a snowmelt prediction program was used that is capable of calculating the snowmelt quantity in the entire drainage basin. This program produces data required for predicting snowmelt quantity from weather forecast values and nearby meteorological observation data (Kurihara et al., 2007) and for distributing these weather data, drainage basin elevations, land use, and other topographical data throughout the Imogawa River basin to create a spatially distributed model capable of reflecting these values in the prediction evaluations and calculating snowmelt. The program has a subprogram to reproduce the flow of the calculated snowmelt quantity in a river course, calculate the predicted water level at the Koimogawa Bridge over the downstream Imogawa River, and use it as an index for determining the alert status for the following day.

\subsection{Post-seismic sediment monitoring}

Following the Mid-Niigata Prefecture Earthquake, surveys based mainly on aerial laser 
measurements were conducted in the Imogawa River basin to clarify changes in the quantity of sediment produced by new and expanded landslides due to snowmelt or heavy rainfall following the earthquake. The following is the quantity of sediment produced by landslides based on the volumetric differences in the topography obtained from digital elevation model data sets for three periods: immediately after the earthquake, May 2005, and May 2006.

From immediately after the earthquake until May 2005 , approximately $600,000 \mathrm{~m}^{3}$ of sediment failed (about $13 \%$ of the failed sediment at the time of the earthquake), and its cause was considered to be snowmelt. From May 2005 until May 2006, approximately $800,000 \mathrm{~m}^{3}$ of soil collapsed (about $17 \%$ of the failed soil at the time of the earthquake). This was caused by about $3,000 \mathrm{~mm}$ of rain and snowmelt. A comparison of the quantity of collapsed soil per unit of time shows that from immediately after the earthquake until May 2005, the amount was approximately $2,600 \mathrm{~m}^{3} /$ day and from May 2005 until May 2006, this was approximately $2,200 \mathrm{~m}^{3} /$ day. This indicates that in the Imogawa River basin, sediment continues to be produced by slope failures.

An examination of the changing sediment yield and runoff in individual basins within the Imogawa River basin shows that in the basins in which a large quantity of collapsed sediment was produced by the earthquake, the quantity of sediment produced by landslides due to snowmelt or rainfall after the earthquake seemed to be larger than in the basins in which a smaller quantity of collapsed sediment was produced at the time of the earthquake.

As a result, even though no serious landslide has occurred so far, the sediment yield and runoff potential still remain high. Hence, careful monitoring activities continue as of July 2007. So far, some rainfall and earthquake events have occurred whose intensities were above the alert level. Each time they took place, the Yuzawa Sabo Office checked landslide occurrence and damage to the erosion control works. This monitoring system needs improvement to enable a faster response.

The post-seismic sediment monitoring will be continued to acquire the basic knowledge and data to be reflected in the updated sabo plans.

\section{CONCLUDING REMARKS}

We presented an overview of the sediment-related disasters caused by the 2004 Mid-Niigata Prefecture Earthquake, together with the risk management response taken by the central government. A large amount of unstable sediment produced by landslides, as well as landslide dams formed by solid soil mass, still remain in the river basin. This unstable sediment may flow out over a long period due to snowmelt or rainfall, affecting the main stream of the Uonogawa River.

Permanent measures are required for landslide dams in Higashi-Takezawa district and other areas based on the suggestions made by the advisory committee and the results of surveys. It is also necessary to formulate a sabo master plan that

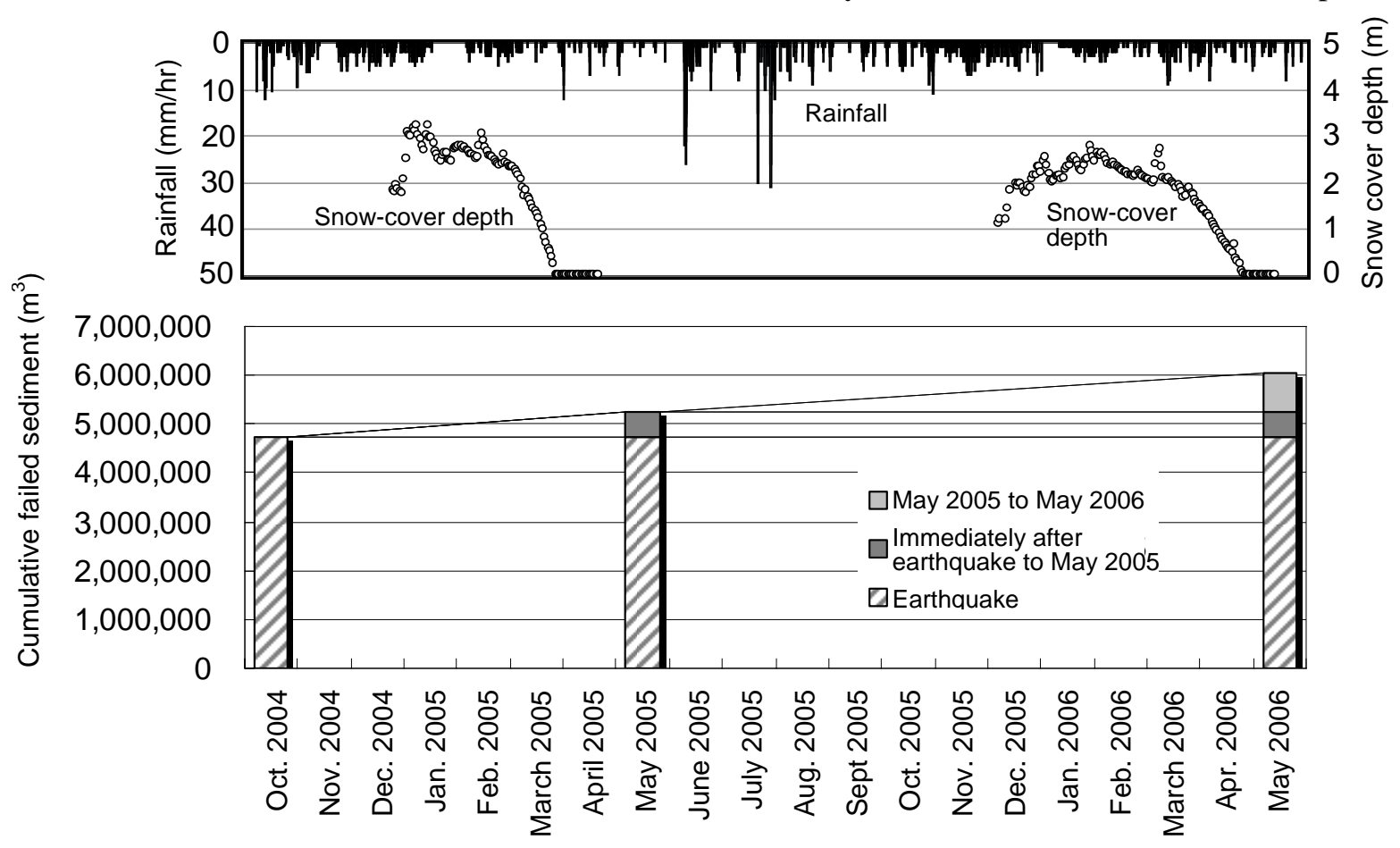

Fig. 5 Temporal change in failed sediment produced in the entire Imogawa River basin. 
reflects the actual state of sediment movement after the earthquake, based on the basic policy proposed by the advisory committee, and coordinated with local restoration plans. In addition, sabo works should be promoted in the entire Imogawa River basin together with the implementation of prevention measures for deep-seated landslides.

The Yuzawa Sabo Office has continued conducting helicopter surveys and terrestrial monitoring after the earthquake to ensure the safety of downstream residents and workers, and to follow up sediment movement phenomena in the river basin for a future revision of the sabo master plan. These monitoring activities also contribute to the efforts of local authorities in providing information on sediment-related disasters in the earthquake-damaged river basin.

Sabo works are considered to be the most fundamental infrastructure elements especially in earthquake-damaged mountainous areas. Implementation and follow-up are necessary to achieve an early and sustainable recovery from the devastation produced by earthquake-induced sediment-related disasters.

\section{ACKNOWLEDGMENTS}

We pray for all the victims of the Mid-Niigata Prefecture Earthquake and acknowledge the contribution of all those who were involved in the emergency efforts. We hope for the full recovery of the damaged communities. The English in this document has been checked by at least two professional editors, both native speakers of
English. For a certificate, see:

http://www.textcheck.com/cgi-bin/certificate.cgi? $\mathrm{id}=\mathrm{YpXgZQ}$

\section{REFERENCES}

Japan Meteorological Agency (1996) Explanation Table of JMA Seismic Intensity Scale, http://www.jma.go.jp/jma/kishou/know/shindo/explane.html

Korup, O. (2002) Recent research on landslide dams-a literature review with special attention on New Zealand, Progress in Physical Geography, 26, 2, pp. 206-235

Plaza-Nieto, G., and Zevallos, O. (1994) The 1993 La Josefina rockslide and Rio Paute landslide dam, Ecuador, Landslide News, 8, pp. 4-6

Kobayashi, I., Tateishi, M., Yoshioka, T., and Shimazu, M. (1990) Geology of the Nagaoka Area, Research Report on Regional Geologies (Geological map 1/50,000), Geological Survey of Japan, p. 132 (In Japanese)

Yanagisawa, Y., Kobayashi, I., Takeuchi, K., Tateishi, M., Chihara, K., and Kato, H. (1986) Geology of the Ojiya Area, Research Report on Regional Geologies (Geological map 1/50,000), Geological Survey of Japan, p. 177 (In Japanese)

N.I.L.I.M et al. (2005) Outline of the on site survey of the damage induced by the 2004 Mid Niigata Earthquake Disaster, N.I.L.I.M. Technical Report, No. 248, pp. 34-36

Costa, J. E. (1988) Floods from dam failures, In Baker, V.R., ed. Flood Geomorphology, pp. 439-463

Kurihara, J., Yamakoshi, T., Irasawa, M., Sasahara, K., Takahashi, M., and Yoshida, M. (2007) Study on the applicability of the simplified snowmelt prediction method to the Imokawa river basin, Niigata Prefecture, Japan, Journal of the Japan Society of Erosion Control Engineering, Vol. 59, No. 6, pp. 47-54 (In Japanese with English abstract) 